\title{
Pelatihan Pembuatan Video Tutorial Gerak Tari Tradisi Lampung sebagai Media Pembelajaran Bagi Guru Seni Budaya SMP di Kabupaten Lampung Timur
}

\author{
Amelia Hani Saputri ${ }^{\star *}$, Lora Gustia Ningsih ${ }^{1}$ Afrizal Yudha Setiawan² \\ ${ }_{1}^{1}$ Pendidikan Tari, Universitas Lampung, Bandar Lampung, 35145, Lampung, Indonesia \\ 2 Pendidikan Musik, Universitas Lampung, Bandar Lampung, 35145, Lampung, Indonesia
}

\begin{abstract}
Abstrak.
Pembelajaran seni tari dimasa pandemi dilaksanakan secara daring. Guru dituntut mampu mengembangkan media pembelajaran dan berkreasi menggunakan tekhnologi dengan membuat video tutorial gerak, yang diyakini efektif dan efisien dibandingkan dengan penjelasan secara lisan dan tulisan. Dalam implementasinya, hal tersebut belum bisa terlaksana. Faktor penyebabnya adalah minimnya referensi serta keterbatasan sarana yang dimiliki guru seni budaya, sehingga berdampak pada minimnya kreativitas guru untuk mewujudkan media pembelajaran. Pelatihan pembuatan video tutorial gerak tari tradisi Lampung sebagai media pembelajaran bagi guru seni budaya SMP di Kabupaten Lampung Timur menjadi penting dilakukan untuk dapat memberikan pengetahuan kepada Guru Seni Budaya dalam merancang konsep dan konten video tutorial gerak tari, teknik pengambilan video pada detail ragam gerak, serta tahapan proses editing. Mitra dalam kegiatan ini melibatkan guru Seni Budaya SMP yang tergabung dalam Musyawarah Guru Mata Pelajaran (MGMP) Kabupaten Lampung Timur. Kegiatan pengabdian berjalan lancar sesuai dengan rencana.Hasil kegiatan menunjukkan bahwa pelatihan dapat meningkatkan pemahaman dan keterampilan guru dalam membuat video tutorial gerak tari tradisi Lampung yaitu tari Bedayo Tulang Bawang. Output dari kegiatan ini adalah video tutorial gerak tari yang dibuat dan dikembangkan oleh guru seni budaya secara individu.
\end{abstract}

Kata kunci.

pelatihan, media pembelajaran, video tutorial gerak.

\section{PENDAHULUAN}

Peningkatan kualitas pembelajaran seni ditengah situasi pandemi Covid-19 terus dilakukan untuk mengoptimalkan terealisasinya pembelajaran menggunakan sistem online/online. Faktor pendukung upaya tersebut ialah ketersedian SDM/ guru seni budaya yang mampu mengelola pembelajaran seni secara online. Guru Seni Budaya harus mampu berkreasi menggunakan teknologi, salah satunya dengan membuat video tutorial sebagai media pembelajaran [1-4]. Ketersediaan video tutorial gerak tari dapat membantu siswa

\section{* Corresponding author: ameliahani@fkip.unila.acid}

Received 1 November 2021; Received in revised form 10 November 2021; Accepted 11 November 2021 Available online 28 December 2021

Lembaga Penelitian dan Pengabdian Kepada Masyarakat

Universitas Lampung 
dalam melakukan pembelajaran secara mandiri kapan saja dan dimana saja, serta dapat memperjelas setiap materi gerak yang diberikan. Tari tradisi Lampung sendiri memiliki karakteristik gerak dengan tempo yang cepat serta pola gerak yang tegas sehingga ketersediaan video tutorial gerak tari tradisi Lampung di masa pandemi ini menjadi sangat mendesak dilakukan. Video tutorial gerak tari tradisi Lampung sebagai media pembelajaran diyakini paling efektif dan efisien dibandingkan dengan penjelasan secara lisan dan tulisan semata. Dengan demikian, materi pembelajaran dapat tersampaikan dengan baik dan target pembelajaran dapat tercapai dengan maksimal.

Pembuatan video tutorial pembelajaran gerak tari urgent dilakukan karena proses pembelajaran tari harus tetap berlangsung meski dalam situasi dan kondisi pandemi, disisi lain pembelajaran tari tidak memungkinkan untuk memberikan materi hanya pada teori dan lisan tentang gerak-gerak yang harus dilakukan, tuntutan pencapaian kompetensi, juga keluhan siswa terhadap sulitnya belajar gerak mandiri tanpa ada media pembelajaran berupa video tutorial. Pembuatan video tutorial gerak tari harus didukung dengan penguasaan teknologi dan ketersediaan sarana dan prasarana seperti kamera, handphone dan aplikasi editing.

Salah satu mitra yang menjadi sasaran untuk mengimplementasikan pembuatan video tutorial pembelajaran gerak tari tradisi Lampung adalah "Guru Seni Budaya tingkat SMP di Kabupaten Lampung Timur" yang tergabung dalam Musyawarah Guru Mata Pelajaran (MGMP) yang berjumlah 20 orang. Minimnya referensi serta keterbatasan sarana yang dimiliki guru Seni Budaya di daerah Kabupaten, berdampak pada minimnya kreativitas guru untuk mewujudkan media pemelajaran yang efektif dan efisien melalui video tutorial gerak tari. Kegiatan Musyawarah Guru Mata Pelajaran (MGMP) Seni Budaya di Kabupaten Lampung Timur rutin dilaksanakan sebanyak dua kali di setiap semester, sehingga guru Seni Budaya yang tergabung memiliki potensi untuk mengembangkan inovasi baru dalam menyusun media pembelajaran berupa video tutorial.

Berdasarkan permasalahan tersebut, maka dirasa penting untuk mengadakan pelatihan pembuatan video tutorial gerak tari tradisi Lampung sebagai media pembelajaran. Melalui program pelatihan ini diharapkan dapat menjadi solusi bagi guru seni budaya tingkat SMP di Kabupaten Lampung Timur dalam membuat video tutorial gerak tari yang berisi detail ragam gerak serta perpindahan pola lantai secara teratur. Output dari pelatihan ini setiap guru seni budaya di Kabupaten Lampung Timur dapat menghasilkan video tutorial gerak tari tradisi Lampung.

\section{METODE}

Kegiatan pelatihan ini dilaksanakan secara daring dengan menggunakan platform Zoom Meeting untuk menyesuaikan kondisi pandemi Covid-19. Kegiatan pelatihan ini melibatkan mitra yaitu Guru Seni Budaya tingkat SMP yang tergabung dalam Musyawarah Guru Mata Pelajaran (MGMP) Kabupaten Lampung Timur. Peserta pelatihan hanya dibatasi sebanyak 20 peserta untuk meminimalisir adanya kerumunan. Metode yang digunakan pada kegiatan ini adalah Ceramah (penyampaian materi) yang diikuti oleh mitra yaitu guru seni budaya. Sedangkan untuk proses pelatihan, digunakan metode Demonstrasi pada teknik pengambilan video dan tahapan proses editing video, transisi video, pembuatan title serta efek video. Kegiatan yang akan dilakukan adalah:

\section{Metode ceramah}

Metode ceramah digunakan oleh pemateri untuk menjelaskan materi inti terkait dengan 
media pembelajaran seni tari.

\section{Metode Demonstrasi}

Metode demonstrasi dilakukan oleh tim pengabdian untuk memperagakan ragam gerak tari Bedayo Tulang Bawang. Metode ini juga didukung dengan media pembelajaran berupa video pembelajaran tari Bedayo Tulang Bawang yang sebelumya sudah disiapkan oleh tim pengabdian.

\section{Bimbingan Teknis}

Bimbingan teknis dilakukan oleh tim pelaksana kepada peserta dalam proses penyusunan konsep dan proses editing menggunakan aplikasi kine master.

\section{HASIL DAN PEMBAHASAN}

\section{Hasil Kegiatan}

Program pengabdian ini berjudul Pelatihan Pembuatan Video Tutorial Gerak Tari Tradisi Lampung Sebagai Media Pembelajaran Bagi Guru Seni Budaya SMP di Kabupaten Lampung Timur yang berlangsung pada tanggal 26-28 Juli 2021. Sebagai Upaya mematuhi peraturan Pemerintah terkait PPKM Level 4 diseluruh wilayah Provinsi Lampung, juga untuk mematuhi protokol pencegahan Covid-19, kegiatan pengabdian ini dilaksanakan secara luring dan daring. Secara luring dilaksanakan oleh tim pengabdian dan panitia yang berjumlah total 10 orang. Secara daring dilaksanakan dalam bentuk webinar menggunakan aplikasi Zoom Meeting. Kegiatan pelatihan ini diikuti oleh 20 orang peserta yang berprofesi sebagai guru seni SMP di Kabupaten Lampung Timur. Kegiatan ini berlangsung selama tiga hari.

Materi-materi yang diberikan dalam pengabdian ini berupa pengetahuan umum mengenai media pembelajaran tari, tahapan merancang konsep dan konten dalam pembuatan video tutorial gerak tari, macam-macam gerak Tari Bedayo Tulang Bawang dan tahapan proses editing, mixing, dan pengisian suara (dubbing). Para pemateri dalam pelatihan ini memiliki kompetensi yang baik dalam bidang tari dan musik. Para pemateri tersebut adalah (1) Amelia Hani Saputri, S.Pd., M.Pd ;(2) Lora Gustia Ningsih, S.Sn., M.Sn; (3) Afrizal Yudha Setiawan, S.Pd., M.Pd.

Pelatihan ini terlebih dahulu dilakukan dengan memaparkan penjelasan umum mengenai media pembelajaran tari, tahapan merancang konsep dan konten dalam pembuatan video tutorial gerak tari oleh Amelia Hani Saputri, S.Pd., M.Pd, kemudian dilanjutkan dengan praktik gerak Tari Bedayo Tulang Bawang oleh Lora Gustia Ningsih, S.Sn., M.Sn. Penyampaian materi terakhir mengenai proses editing, memadukan gambar dengan suara dan musik (mixing), dan kegiatan pengisian suara (dubbing) dipaparkan oleh Afrizal Yudha Setiawan, S.Pd., M.Pd. Selain itu kegiatan pelatihan ini juga dilakukan dengan memberikan bimbingan bagi peserta dalam membuat rancangan pembuatan video tutorial gerak tari yang dibimbing oleh ketiga pemateri. Berikut adalah alur pelaksanaan kegiatan pengabdian yang dilakukan secara daring melalui aplikasi zoom meeting;

1) Penjelasan materi tentang media pembelajaran tari, manfaat dan fungsi video tutorial tari, penjelasan cara merancang konsep dan konten dalam pembuatan video tutorial gerak tari;

2) Penjelasan materi tentang gerak tari tradisi Lampung dan teknik pengambilan video 
pada detail ragam gerak

3) Penjelasan tentang tahapan proses editing yaitu proses pemaduan gambar dengan suara dan musik (mixing), dan kegiatan pengisian suara (dubbing)

Pada pelatihan ini, seluruh peserta juga diberikan e-modul tari Bedayo Tulang Bawang beserta video pembelajarannya. Hal ini guna menunjang keterampilan para peserta pelatihan untuk memahami lebih dalam mengenai materi gerak tari yang diberikan. Peserta pelatihan juga diberikan video tutorial penggunaan aplikasi kine master yang akan digunakan untuk proses editing video dan mixing musik. Berikut adalah e-modul dan video pembelajaran tari Bedayo Tulang Bawang yang disampaikan kepada peserta didik.

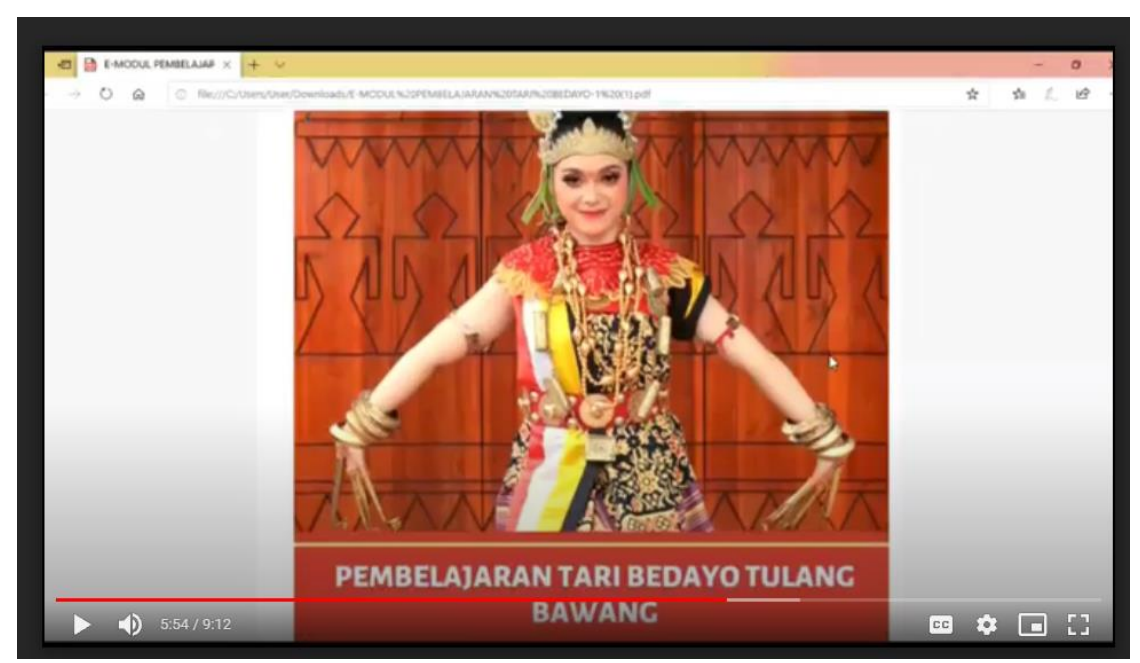

Gambar 1. E-modul Pembelajaran Tari Bedayo Tulang Bawang Sumber: tangkapan layar (saputri, 2021)

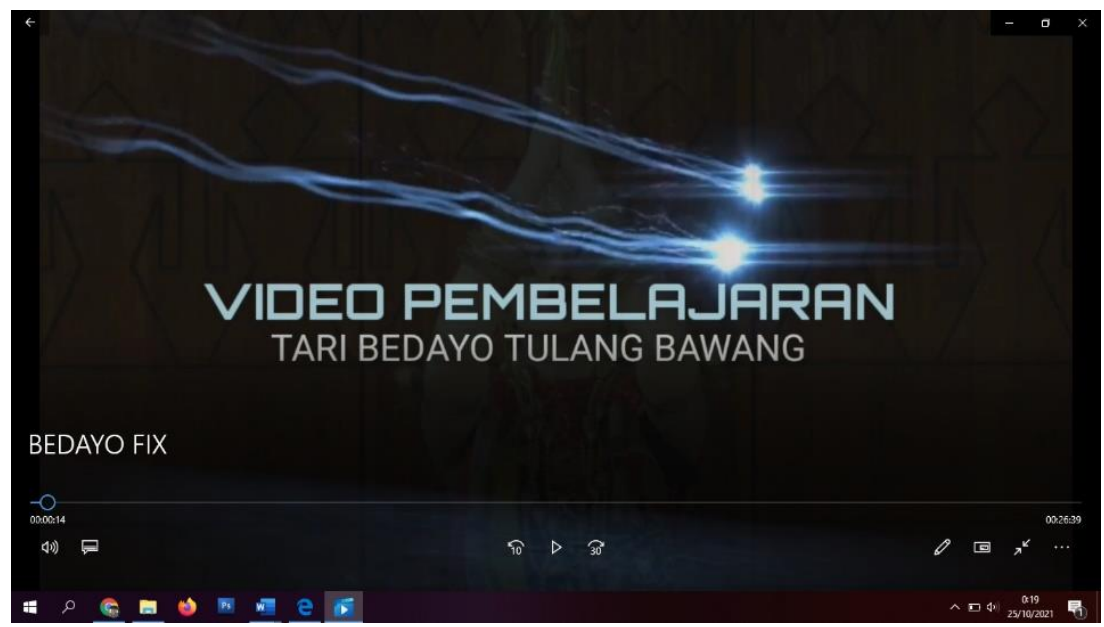

Gambar 1. Video Pembelajaran Tari Bedayo Tulang Bawang Sumber: tangkapan layar (saputri, 2021)

Selanjutnya dilanjutkan dengan pemaparan materi mengenai media pembelajaran, tantangan pembelajaran daring, serta cara membuat media pembelajaran tari yang kreatif dan inovatif yang mampu menarik minat peserta didik, serta cara pembuatan video tutorial menggunakan aplikasi kine master yang langsung di praktikkan oleh seluruh peserta pelatihan. Adapun dokumentasi dari kegiatan tersebut dapat dilihat pada gambar berikut. 


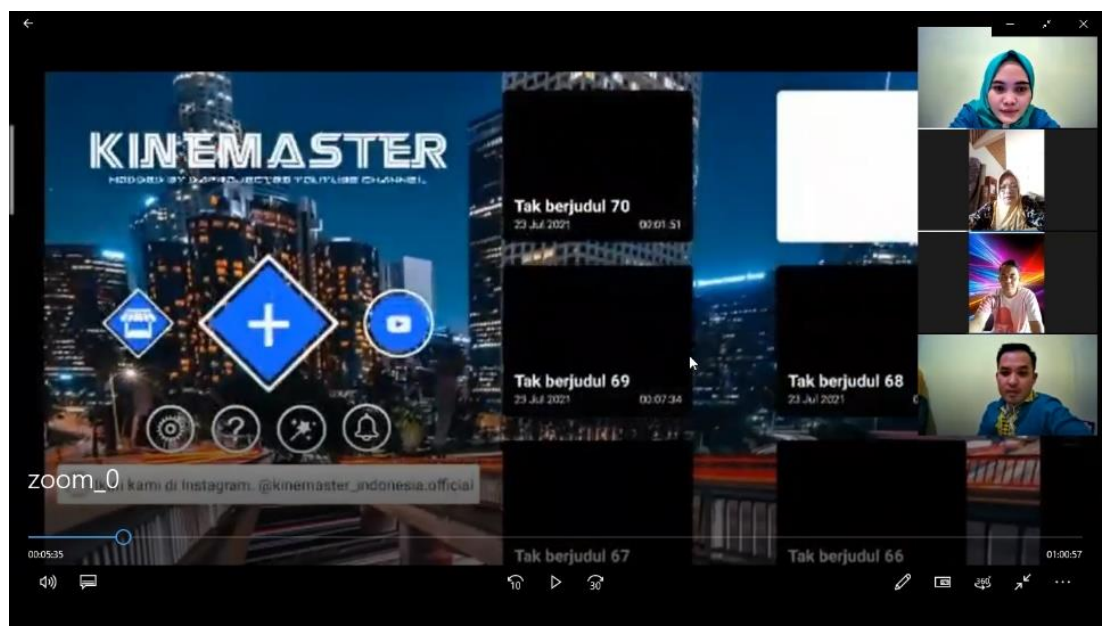

Gambar 3. Tangkapan Layar cara merancang konsep dan konten menggunakan aplikasi kine master

Pemaparan materi selanjutnya berisi penjelasan materi tentang gerak tari tradisi Lampung yaitu gerak tari Bedayo Tulang Bawang dan teknik pengambilan video pada detail ragam gerak. Adapun dokumentasi dari kegiatan tersebut dapat dilihat pada gambar berikut.

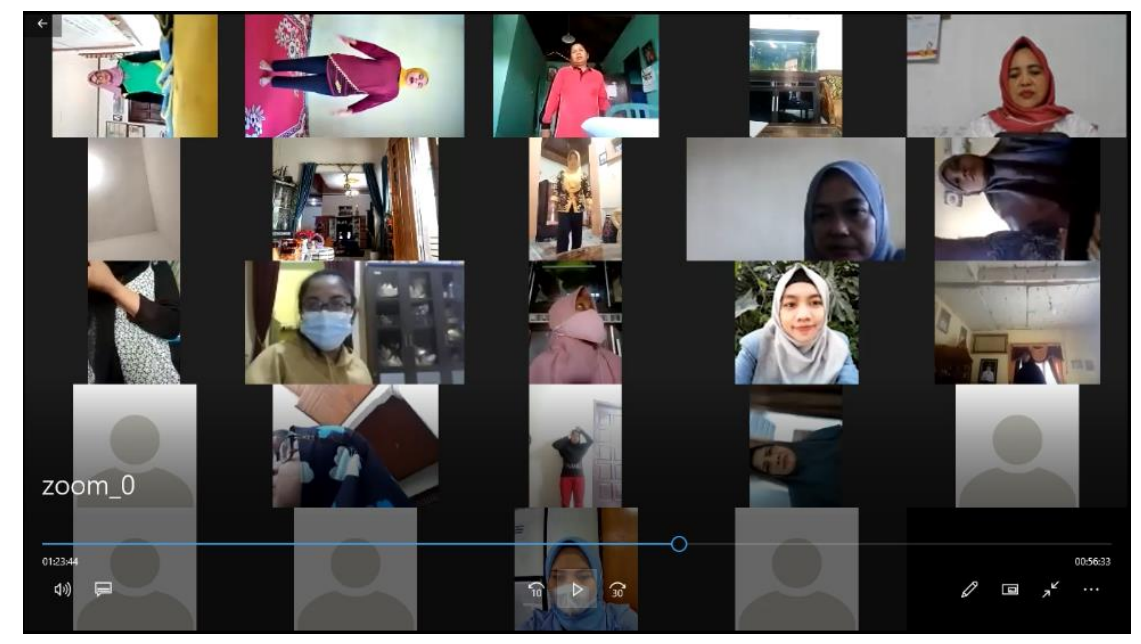

Gambar 4. Tangkapan Layar materi gerak tari Bedayo Tulang Bawang

Output dari kegiatan pelatihan ini berupa video tutorial gerak tari Bedayo Tulang Bawang, yang dibuat oleh masing-masing peserta pelatihan. Setelah pemaparan materi selesai, seluruh peserta pelatihan diberikan waktu untuk langsung mempraktekkan tahapan dalam merancang dan membuat video tutorial gerak tari Bedayo Tulang Bawang. Peserta pelatihan diberi waktu satu hari untuk melakukan proses rekaman gerak dan editing menggunakan aplikasi kine master. Pada pelatihan di hari berikutnya, peserta pelatihan mengumpulkan video yang sudah dibuat untuk selanjutnya di review bersama pemateri. Berikut adalah presentasi hasil pembuatan video tutorial yang dilakukan oleh peserta pelatihan. Berikut adalah dokumentasi dari kegiatan tersebut dapat dilihat pada gambar berikut. 


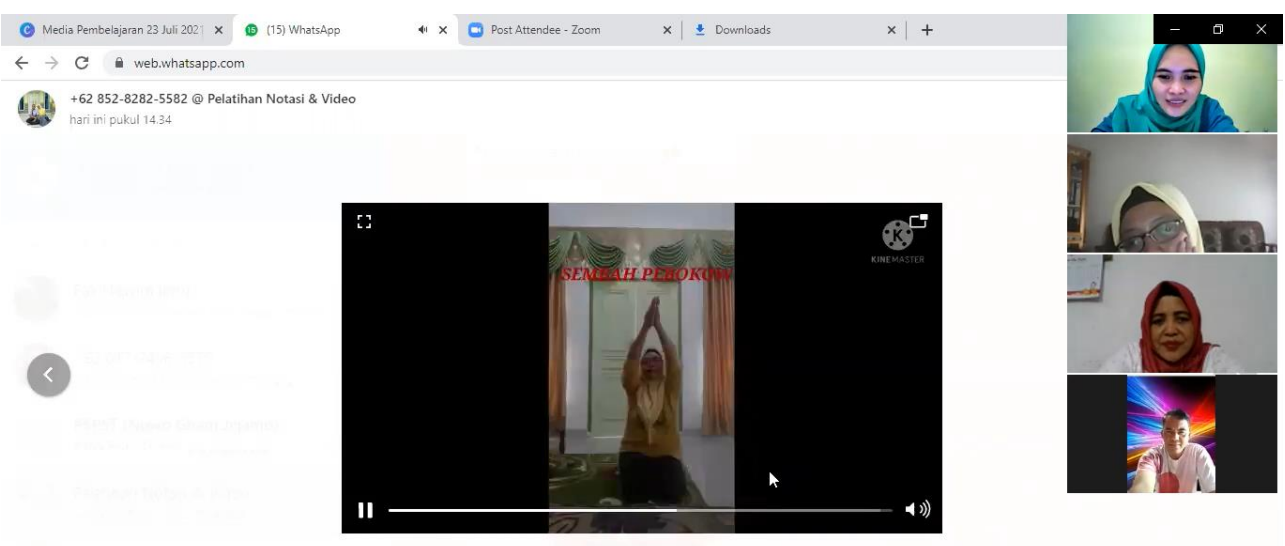

Gambar 5. presentasi uji coba pembuatan video tutorial oleh peserta pelatihan Memainkan Pola Ritmis

\section{Pembahasan}

Kegiatan pembuatan video tutorial gerak tari Tradisi Lampung sebagai media pembelajaran bagi guru Seni Budaya SMP di Kabupaten Lampung Timur yang berlangsung selama tiga hari berjalan lancar dan mendapatkan respon yang positif dari guru-guru seni budaya selaku peserta pelatihan. Meskipun kegiatan pelatihan dilakukan secara daring, namun antusias peserta pelatihan sangat besar. Hal tersebut terlihat dengan adanya diskusi antar peserta dengan pemateri melalui WA Group. Antar peserta saling bertukar informasi, dan saling bekerjasama dalam memahami materi dan menyelesaikan tugas pelatihan. Dalam kegiatan pelatihan ini, para peserta memiliki pengetahuan dan keterampilan baru dalam membuat video tutorial gerak tari yang aplikatif dan mudah diterapkan.

Kegiatan PKM ini merupakan upaya dalam meningkatkan profesionalisme guru seni budaya dalam menciptakan ruang kreatif baru dalam berinovasi membuat media pembelajaran tari yang dapat digunakan untuk pembelajaran daring. Output dari pelatihan ini dapat digunakan sebagai bahan ajar seni tari. Secara keseluruhan materi dapat dipahami dengan baik oleh para peserta. Peserta pelatihan diberi tugas praktik membuat video tutorial gerak tari Bedayo Tulang Bawang menggunakan aplikasi kine master yang dibimbing langsung oleh tim pengabdian dari Program Studi Pendidikan Tari.

Pelatihan ini memberikan dampak positif bagi para peserta pelatihan. Peserta pelatihan memiliki wawasan dan pengetahuan baru tentang media pembelajaran gerak tari. Respon peserta pelatihan sangat positif, sebab narasumber dalam pelatihan ini merupakan dosen yang ahli di bidang tari. Materi pembuatan video tutorial gerak tari ini secara umum berguna untuk memberikan pemahaman yang fundamental bagi seorang guru seni agar mampu membuat dan mengembangkan media pembelajaran yang inovatif dan kreatif. Namun demikian, terdapat beberapa kendala dalam pelaksanaan kegiatan pelatihan ini, diantaranya adalah sebagai berikut. 1. Kegiatan pelatihan dilakukan secara daring, sehingga proses interaksi antara pemateri/narasumber kepada peserta pelatihan menjadi terbatas. Proses bimbingan yang dilakukan secara daring tentu sangat berbeda jika dilakukan secara tatap muka. 2. Pemaparan materi pelatihan dilakukan dalam waktu yang terbatas. Hal tersebut disebabkan karena dalam pelatihan daring dibutuhkan kuota internet yang cukup besar dan perangkat komunikasi yang memadai. Tidak semua peserta mengikuti kegiatan pelatihan dengan menggunakan PC/Laptop, dan hanya menggunakan smartphone.

Dari keseluruhan kegiatan pelatihan, dapat diambil sebuah gagasan bahwa penyusunan rancangangan pembuatan video tutorial gerak tari membutuhkan pemahaman 
komprehensif dari berbagai aspek. Untuk meningkatkan motivasi peserta pelatihan, tim pengabdian memberikan sertifikat yang diberikan kepada peserta yang mengikuti serangkaian kegiatan dari awal sampai akhir. Selain pemberian sertifikat, tim pengabdian juga memberikan buku materi pelatihan dalam bentuk soft file.

\section{KESIMPULAN}

Berdasarkan hasil kegiatan pengabdian yang telah dilakukan dapat ditarik kesimpulan bahwa hasil pelatihan "Pembuatan Video Tutorial Gerak Tari Tradisi Lampung Sebagai Media Pembelajaran Bagi Guru Seni Budaya SMP di Kabupaten Lampung Timur" dapat terlaksana dengan baik. Hal ini ditunjukkan dengan beragamnya rancangan video tutorial yang disusun oleh peserta pelatihan. Melalui pengabdian ini para peserta telah memiliki pengetahuan dan keterampilan mengenai teknik dalam pembuatan video tutorial tari menggunakan aplikasi kine master.

\section{DAFTAR PUSTAKA}

[1] Muhson, A. (2010). Pengembangan media pembelajaran berbasis teknologi informasi. Jurnal Pendidikan Akuntansi Indonesia, 8(2).

[2] Rusman, (2009). Manajemen Kurikulum. Jakarta: PT Raya Grafindo Persada.

[3] Rosalina, S. S. (2018). Pembuatan Video Tutorial Sebagai Media Pembelajaran Florist Pada Kompetensi Keahlian Akomodasi Perhotelan (Doctoral dissertation, Universitas Pendidikan Indonesia).

[4] Yuanta, F. (2020). Pengembangan Media Video Pembelajaran Ilmu Pengetahuan Sosial pada Siswa Sekolah Dasar. Trapsila: Jurnal Pendidikan Dasar, 1(02), 91-100. 